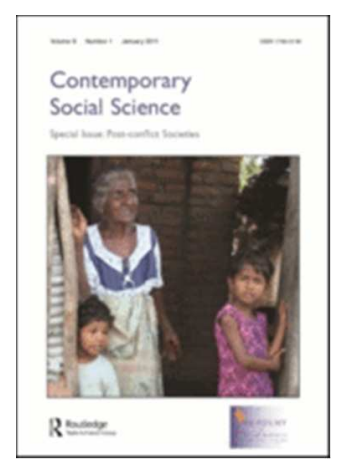

\title{
The Borders of Booze Britain: Alcohol control and nationality
}

\begin{tabular}{|r|l|}
\hline Journal: & 21st Century Society \\
\hline Manuscript ID: & Draft \\
\hline Manuscript Type: & Original Paper \\
\hline Keywords: & Public discourse, Policy, Migration, Historical issues \\
\hline & $\begin{array}{l}\text { This paper seeks to understand how United Kingdom alcohol control } \\
\text { policies, historically and currently, are both informed by and seek to inform } \\
\text { how we conceptualise the nation and nationality. Using the latest } \\
\text { minimum price per unit of alcohol policy as a point of departure and setting } \\
\text { it the context of over three hundred years of alcohol controls, this paper } \\
\text { exposes how the internal contradictions inherent in alcohol regulation are } \\
\text { obscured by the deployment of nationalism as a rhetorical device }\end{array}$ \\
\hline
\end{tabular}




\title{
The Borders of Booze Britain: Alcohol controls and nationality
}

\begin{abstract}
This paper seeks to understand how United Kingdom alcohol control policies, historically and currently, are both informed by and seek to inform how we conceptualise the nation and nationality. Using the latest minimum price per unit of alcohol policy as a point of departure and setting it the context of over three hundred years of alcohol controls, this paper exposes how the internal contradictions inherent in alcohol regulation are obscured by the deployment of nationalism as a rhetorical device

Keywords
\end{abstract}

Alcohol, nationality, border controls 


\section{The borders of booze Britain}

\section{Introduction}

This paper argues that, both historically and in the current era, policies regarding the control of the sale and use of alcohol have as much to do with notions of nationality and the nation state as they do with public health, economy or crime and disorder.

The current UK coalition government has recently announced a policy of minimum price per unit for alcohol sales (Leicester \& O'Connell, 2012). Although there is a chance that the European Union could overturn this policy under anti-competition laws, the policy raises many interesting questions of class and nationality as they relate to drinking. By setting a minimum price, this policy could be viewed as akin to a regressive taxation on drinkers, a sin tax to use John Stuart Mill's parlance (Mill, 1859), although clearly this is not a tax in the normative fiscal sense as no extra duties will be collected by the treasury. By setting the minimum price per unit of alcohol, prices of expensive, therefore exclusive, beverages will be unaffected, yet the cost of the cheapest supermarket and off-licence sold alcoholic drinks will increase. Therefore we can say without much doubt that the consumers of cheap drinks, and therefore most likely the poor, are to be greatest affected by minimum price setting. As the price is set per unit of alcohol contained in the drink and not by the overall volume of the beverage, the greatest increase in cost to the consumer will be those who consume cheap yet strong drinks. As others have observed, there is an element of class conceit to this policy (Brockley, 2012) as the stated aim is to reduce binge drinking, the thinking behind the policy must therefore assume that binge drinking is a malaise of the poor, that the better-off do not engage in such behaviour, or if they do, there are no negative 
social or public health consequences of this behaviour. Thus, it is relatively straightforward to argue that there is a class dimension to this policy; while this is clearly important for a number of reasons, this paper will argue that there is also an issue of nationality that is embedded in this policy, as there has been in many attempts to control the sale and consumption of alcohol throughout the modern history of Britain. The conjecture of this paper is that this latest attempt to manage alcohol use can be utilised to reinforce notions of nationality and consequently has the potential to be used as leverage to reinforce national border controls.

This paper will first provide a distilled history of alcohol control policies in the UK to illustrate how alcohol has been used historically to reinforce divisions of nationality and to construct the other. As Holt observes;

"Alcohol is a very useful lens through which to explore larger and more obvious historical changes such as industrialisation and the rise of the state" (Holt, 2006, p. 1).

Both processes (industrialisation and the rise of nation states) have, instrumentally or as a consequence, created social divisions and had enduring implications for notions of culture and identity. With industrialisation, there have been profound effects on the class structure along the lines of the ownership of the means of production and the division of labour (Marx, 1976). Others have argued that post-industrialisation also has an impact on class and alcohol consumption (Haywood \& Hobbs, 2007), with the growth of the night time economy as a political and economic response to a post-Fordist paradigm. However, as stated, the focus of this paper is not the relationship between alcohol consumption and social class, however it is worth keeping in mind the how notions of social class, and certainly social class deficit, inform debates and policies about the consumption of alcohol beverages. 
Rather, the focus of this paper is to explore how alcohol controls relate to discourses of nationality.

As recent as 2004 the then British Prime Minister Tony Blair gave a speech referring to binge drinking as the "new British disease" (Rayner, 2004), as we will uncover; how and how much the British drink has often been used to construct a sense of national pride and deficit both for those identified as British and those identified as non-British. From the Irish who "revels in drink to the point of the most bestial drunkenness" (Engels, 1993, p. 103) of 19th Century Manchester to the late 20th Century demonization of "lager louts" (Mares, 2001, p. 153), alcohol has been used as a marker of nationality and national identity. Therefore we will explore how the current policy paradigm of minimum alcohol unit price fixing continues this tradition by looking at in whose interest this policy benefits. At this stage of the analysis we will see that both the alcohol industry and the criminal fraternity are set to profit from the policy. Given the commonly-perceived ideological standpoint of the current UK coalition government, it may be obvious as to why they might wish to give support the corporate brewing industry, it is well known that the alcohol industry is a great supporter of the incumbent Conservation Party (Bower \& Cox, 2010), what is initially less obvious is to why the government would want to support organised crime, as an clear consequence of minimum price setting is likely to be an increase in both the volume of alcohol smuggling and in the profits to be made from such nefarious activities. As we will see, this policy gift to those engaged in unlawful business could provide the subtext for further policy shifts in relation to nationality and nationhood. Finally this paper will look at how the implementation of the alcohol minimum price setting policy could be utilised to provide the justification for enhanced border controls. For if increasing the price of legally available alcohol does lead to an increase in contraband, then there may be calls to tighten UK border 
controls, thus, in the final analysis, this paper is interested in the relationship between 'Booze Britain' and 'Fortress Britain'

As this paper will explore, alcohol has for centuries defined who we are in terms of nationality, as by extension, define who is the other or outsider. If this is framed as an issue of nationality, then it must also be an issue of borders. For without borders, even if they may be elastic and porous, it is challenging to either define the nation or any sense of imagined community which may be corollary to the construction of nationality (Anderson, 1991). Historically, attempts to control the sale and consumption of alcohol have had some effect on how the nation-state practices border controls (Ludington, 2006). This paper is focused on the context of the United Kingdom, but we could also use the impact of the $18^{\text {th }}$ amendment to the US constitution as a comparative example. The prohibition of alcohol led to a massive growth in illegal bootlegging, or alcohol smuggling. This in turn, provided the US Coastguard Service with further policing roles in order to stem the supply of illegal alcohol being imported into the United States of America.

\section{A distilled historical context}

In order to provide the historical context to the preposition of this paper, will involve the analyse some key events of three historical epochs; The Act of Union with Scotland and London's Gin Craze of the $18^{\text {th }}$ Century; Irish immigration and industrialisation in the $19^{\text {th }}$ Century and binge drinking and the accession of eight Eastern European countries to the European Union at the beginning of the $21^{\text {st }}$ Century. As we will see, the relationship between how we consume alcohol and how we conceptualise nationality is not new. This section on the history of alcohol consumption in Western contexts is not exhaustive but rather provides exemplars that according to Holt: 


$$
\begin{aligned}
& \text { "[...] not even the commercial interests that control the production of alcohol can } \\
& \text { totally regulate, much less control, either the meaning or myriad functions of alcohol } \\
& \text { in Western life" (2006, p. 7). }
\end{aligned}
$$

The first era considered in this paper, the early to mid $18^{\text {th }}$ Century, has two artefacts that have a bearing on the relationship between alcohol control and the nationality. Edinburgh is the epicentre for one series of events whereas London sets the scene for another set of independent events, however both narratives evoke notions of national identity, and they also both have a bearing on relations with the French.

Starting in Scotland, Ludington (2006), examines how French claret wine became the preferred drink of the Scots around the time of the Act of Union. Before the Act of Union, claret was popular in Scotland whereas it was not so in England, this could be due to differences in taxation and duty regimes. However the Act of Union and equalisation of duties dramatically raised the cost of imported claret in Scotland, for English duties on French wine were more costly. Instead of having the effect of reducing claret consumption in Scotland, the increase in duty, according to Ludington's research, only served to increase the illegal importation of claret. At least part of the evidence for the popularity of claret in Scotland before the Act of Union was the Wine Act of 1703, which according to Ludington, "established claret as a symbol of Scottish independence and as a commodity to symbolically defy the English" (2006, p. 167). England was at war with France and therefore the drinking of French wine could be viewed as an act of defiance. Furthermore, the English duties on imported alcohol, which were relevantly steep compared to those of the pre-Union Scots, were in part to pay for the war against France. Thus the act of drinking French claret had a twofold influence on the Scots relationship with the English; firstly as a symbol of defiance and secondly by being financially able to enjoy more luxurious wine. 
Thus, through this period, we can observe how the consumption of a certain alcoholic beverage, namely claret, was used to both define and reinforce Scottish nationality as superior to that of the imperialistic English. As the Scot William Clelland, wrote from London in 1705 ,

“All the wine here is poison'd and all the women pox't at least I would fain fancie so whylst I have no monie." (Ludington, 2006, p. 169)

However, if we take Ludington's treatise beyond the Act of Union of 1707, which lead to the equalisation of alcohol duties on French wine between Scotland and England, we see that claret consumption in Scotland did not necessarily reduce; rather, it propagated the illegal importation of claret as a further act of defiance. This increase in claret smuggling, thus served two purposes; it increased the profit from importation of wine, as no duty was being paid, and it reinforced the popular opposition to the new customs and duties (Ludington, 2006, p. 172)

At the same time as the Scottish were imbibing claret as a symbol of opposition to English imperialism, London was experiencing a alcohol consumption frenzy popularly referred to as the 'gin craze'. As exemplified by Hogarth's 1751 print 'Gin Lane' with its depiction of morally deficient behaviour brought on by the overconsumption of gin. Much has been written about the impact and the attempts to control Londoners' taste for gin in the $18^{\text {th }}$ Century; however, in thinking about nationality we need to look at the causes of the gin epidemic.

Gin was first popularised amongst the English at the beginning of the $18^{\text {th }}$ Century by soldiers returning from the continent from involvement in the war of Spanish succession (Maples, 2012). At that time, the most popular alcoholic beverage in England was beer. However the distillation and production of gin was vigorous promoted by the English 
government. The perceived rationale for this was twofold; firstly to boost the rural economy by creating a new market for grain producers and secondly, to create a domestic challenge to foreign imports, particularly French brandy (Holt, 2006). The French at this point were in hostilities with the English. In order to achieve these aims, the importation of spirits from foreign countries was duly banned and no licence was required for the production of gin, unlike alehouses (Maples, 2012). Therefore gin was cheap and plentiful with few obvious competitors. These conditions lead to the extreme consumption of gin by the poor of London, seemingly a cheap and available distraction from the harsh conditions of living in London at that time. At the height of the 'gin craze' Londoners were consuming over 11 million gallons of gin a year (Maples, 2012). It is worth bearing in mind that at this time London's population was between one and one and a half million, which gives some idea of the vast quantity of gin the populace of the capital were consuming. The social impact of this gin epidemic is well documented (Maples, 2012), including increased mortality, crime, disorder and child mortality. Yet given the unprecedented detriment to health and social wellbeing, it took the British authorities nearly 50 years to get on top of the problem after a succession of botched legislation (Maples, 2012).

So, the gin craze of the $18^{\text {th }}$ Century had its roots in both economic policy and through the process of defining and reinforcing the nation-state. As the Scots were consuming claret to define and reinforce their sense of national identity also Londoners were doing as a response to a series of policies to promote the English economy and English independence in a hostile European context. Thus by looking at the historical context of the $18^{\text {th }}$ Century, we see that some of the themes that underscore our contemporary concerns regarding 'booze Britain' and Blair's new British disease of binge drinking have some echoes down the ages. 
If we look at some features of $19^{\text {th }}$ Century England, we can identify further themes that have some contemporary resonance. As we saw before it was an Act of Union with Scotland in the $18^{\text {th }}$ Century that had an effect on popular practices and rituals around alcohol. Thus the Act of Union of 1801 with Ireland must also have some bearing on how we came to view the Irish, as a problematic drinker in the context of industrial England. Taking Engels famous description of the Irish in Manchester in the middle of the 19th Century as a point of departure;

"And since the poor devil must have one enjoyment, and society has shut him out of all others, he betakes himself to the drinking of spirits. Drink is the only thing which makes the Irishman's life worth having, drink and his cheery care-free temperament; so he revels in drink to the point of the most bestial drunkenness. The southern facile character of the Irishman, his crudity, which places him but little above the savage, his contempt for all humane enjoyments, in which his very crudeness makes him incapable of sharing, his filth and poverty, all favour drunkenness. The temptation is great, he cannot resist it, and so when he has money he gets rid of it down his throat. What else should he do? How can society blame him when it places him in a position in which he almost of necessity becomes a drunkard; when it leaves him to himself, to his savagery?" (Engels, 1993, pp. 103104)

Engels classic ethnography describes the Irish immigrants of Manchester in less than favourable terms. However it must be noted that Engel's thesis was to document the alienation of Manchester's working class during the industrial revolution. Although Engel's identifies the Irish as almost savage in nature and divisive to working class solidarity by providing a wage drag, or even through the importation of scab labour, we could interpret 
Engel's description as symptomatic of the lumpenproletariat, Marx's reserve army of labour (Marx, 1976). Indeed, a close reading of the Engels passage alludes to some sympathy for the plight of the Irish worker,

"How can society blame him when it places him in a position in which he almost of necessity becomes a drunkard; when it leaves him to himself, to his savagery?" (Engels, 1993, p. 104)

However we choose to read this passage, it is self-evident that Engel's identifies the Irish with drunkenness. However, citing The Report on the State of the Irish Poor in Great Britain, E.P. Thompson contextualises the drinking behaviour of the Irish in manufacturing England:

"On the Saturday night, when they receive their wages, they first pay the score at the shop... and their rent... and when their debts are paid, they go drinking spirits as long as the remnant of their wages holds out. On the Monday morning they are penniless." (Thompson, 1963, p. 476)

So, depending on one's reading of Engels and Thompson, it can be implied that excessive drinking with which the Irish poor appear to be associated with, can be viewed as either a moral deficit of nationality or as a solace from exploitation, poverty, discrimination and dislocation.

As both authors observe, the plight of the Irish working poor in England in the $19^{\text {th }}$ Century is an amalgam of the effects of war, famine, unskilled work, low wages and Diaspora. Nevertheless, as Thompson notes, “[...] Irish labour was essential for the Industrial Revolution [...]" (1963, p. 473) as their labour was cheap, relative to English workers, and they were demoralised to the point that they would undertake the "most disagreeable kind of course labour" (Ibid.). 
Thus by constructing the Irish immigrant of industrial England as having the character of "most bestial drunkenness" (Engels, 1993, p. 103) enabled the further exploitation by the industrial bourgeoisie in the accumulation of capital and the suppression of workers' wages. So our evidence of the relationship between notions of nationality and the consumption of alcohol continue to have resonance from the $18^{\text {th }}$ Century and into the $19^{\text {th }}$ Century.

If we take this notion of the impoverished, hardworking and drunk Irish immigrant forward over one hundred years to the beginning of the $21^{\text {st }}$ Century and replace 'Irish' with 'East European', the similarity of popular discourse in the United Kingdom is startling. While we could frame the popular notion of the bestially drunk Irish migrant as part of the lumpenproletariat of the Industrial Revolution, we can view the popular image of heavy drinking East European migrants as part of the precariat of our current epoch (Standing, 2011).

The accession of the eight east European countries (Cyrus, Czech Republic, Estonia, Hungary, Latvia, Lithuania, Malta, Poland, Slovakia and Slovenia - collectively known as the A8 countries) to the European Union in 2004 resulted in the UK Government putting into place:

“[...] transitional measures to regulate A8 nationals' access the labour market (via the Worker Registration Scheme) and to restrict access to benefits." (Mills, Knight, \& Green, 2007, p. 4)

However, as Standing notes, when it comes to economic immigration, governments often claim, “[...] they are limiting migration while facilitating the growth of a low-wage disposable labour supply." (Standing, 2011, p. 91). Whereas the Irish in 19th Century England provided the "course labour" (Thompson, 1963, p. 476) for the Industrial Revolution, A8 immigration provides a similar role in advanced capitalism of the reserve 
army of labour by responding to the needs of flexibilised labour markets, becoming part of a high risk, low wage, insecure labouring class Standing refers to as the precariat (Standing, 2011).

As stated at the beginning of this paper, social class is an important aspect of alcohol policy but for the purposes of this argument we need to put this to one side, as nationality is our focus. This is not to deny that that there are important, valid and relevant intersections between class and nationality, however let us not confound the argument.

\section{Discussion}

So our brief journey through some key eras of British history reveals that at times the Scottish, the English, the Irish and the Polish (for the Polish are the largest nationality to move to the UK following the A8 accession (Mills et al., 2007)) have all been, and to varying degrees still are, defined and identified in terms of their approach to the drinking of alcoholic beverages. Many of these often played out in stereotypes of popular culture. The question remains, how did problematic, excessive, heavy or binge drinking become an issue so seemingly entwined with Britishness? From 'booze Britain' to Blair's new British disease to Brits abroad, the popular notion seems to be of the behaviour of the British is rather unpleasantly alcohol-fuelled. Furthermore, what ideological function does this notion the excessively-imbibing Brit perform? For it must be ideological as the evidence suggests that despite the hype and the hyperbole, British alcohol consumption has been falling for several years (Morgan, 2011). Furthermore, the apparatus of alcohol regulation, as Valverde observes, “[...] does not seek to maximize health but rather to organize and regulate consumption, producing ordered, disciplined drinkers" (1998, p. 144). She goes on to state:

"Liquor licensing and control systems, whatever their particularities, all share the difficult position of having the regulation of personal consumption as their objective 
- an objective rather out of keeping with the logic of liberalism" (Valverde, 1998, p. 145).

This gives us a useful lens to develop conjecture to understanding the rhetoric of 'British' problem drinking. By utilising the ideologies of the nation and nationality as a framework for advocating controls and regulation of alcohol consumption, policy-makers, and those who seek to influence them, can neatly sidestep this internal contradiction. Foregrounding a perceived national problem of disordered drinking and therefore rallying behind the flag of the health of the nation, allows governments to enforce regulation without appearing at odds with the underlying political ideology of deregulation and laissez-faire policies. Furthermore, by acknowledging the post-Fordist night time economy agenda of contemporary post-industrial Britain, one could deduce that using the proxies of both public health and law and order to regulate alcohol consumption, enables the continued development and investment in an economically-potent alcohol industry while appearing to pour scorn on its social consequences. By deploying the evocative ideology of nationality, which as Anderson notes is so powerful as a rhetorical device that citizens will wilfully die for its cause (Anderson, 1991), governments can scaffold policies for the regulation of individual behaviour while seemingly appear not at odds with the underlying political doctrine of deregulation and reification of markets. This prioritising of the needs of the market, as Adorno opines, leads to the dominance of the exchange-value of commodities, this dominance obscures the original use-value allowing the commodity to take on a new use-value that can be any number of cultural associations and assumptions (Adorno, 1991). Alcohol is one such commodity whereby the new use-value contains cultural associations and assumptions we could package as nationality or nationalism. 


\section{The New policy agenda}

The current UK government's recent policy announcement regarding alcohol minimum price setting seemingly has two groups of clear beneficiaries and one group of losers. The losers are those who buy cheap alcoholic beverages, as the policy will increase the cost of drinking regressively to the poorest. The potential winners from this policy are primarily the alcoholic beverage industry and secondly those involved in the illegal importation of alcohol. According to the Institute for Fiscal Studies fixing the price per unit at 40p (which is the government's proposal) would lead to transfers of revenues of up to $£ 850$ million per year to the alcohol industry (Leicester \& O'Connell, 2012), although this figure does not account for any behaviour changes as a result of the policy, it clearly demonstrates the potential benefit to the alcohol industry. Also, as this policy does not constitute a duty, there will be no increase in revenue to the treasury. Potentially the opposite is true, if the policy has its stated desired effect of reducing alcohol consumption, then the treasury is going to lose income from alcohol duties. This policy seems to lack coherence in terms of political philosophy, as British Prime Minister David Cameron stated, “This is a national problem and it needs a government to focus on it", words that would have John Stuart Mill inebriated with fury, yet this is a government which has set about the retrenchment of social policy like none before. As Valverde observes (1998), all attempts at alcohol control have a poor logical 'fit' with liberalism. Licensing laws, controls on sales and consumption, and prohibition all create impediments to free markets, yet states that enact extreme forms of controls, for example some Islamic states, to not experience a crisis of legitimacy. This then raises the question of how the state, any state not just theocracies; can have systems that control alcohol at all. By raising the spectre of the nation-state and applying it to notions of national deficiency, enables the State to differentiate alcohol as distinct from other forms of beverage in special need of control and management. Evoking the mantra of 
'booze Britain' as a national deficiency, enables the furthering of controls on the sale of alcohol, seemingly without contradiction, in the context of (neo-) liberalism.

The raising of the price of low cost alcoholic beverages in the UK could have a significant impact on the frequency and profitability of alcohol smuggling. According to the figures from HM Revenues and Customs (UK Government agency tasked with both collecting duties and enforcing borders), the alcohol smuggling industry costs the exchequer $£ 1.2$ billion per year in unpaid duties (Norman, 2012) and that much of the business of alcohol trafficking is controlled by "organised criminals" (HMSO, 2010). As with the Scottish consumption of claret with the equalisation of duties and tariffs after the Act of Union had an effect on the quantity and profitability of illegal alcohol smuggling in the $18^{\text {th }}$ Century, it would be foolhardy to believe that increasing the minimum price per unit of alcohol will not have an effect on the illegal alcohol trade. This thought exposes another internal contradiction of the minimum alcohol price policy. On one hand the policy evokes the idea of nationality as a vehicle to deploy regulation of individuals within the nation, yet on the other hand, it provides the incentive for increasing criminal activities at the borders of the nation. As previously stated, nationalism requires a nation and the nation requires boundaries, although these boundaries may be both elastic and porous, thus if the boundaries of the nation in some way define nationality. Therefore, there is a significant poverty of logic with the policy itself. For it would appear contradictory to deploy the nation as a rhetorical device while seemingly setting the scene for increasing strain on the national borders which increased illegal smuggling will inevitably create. Yet maintaining or indeed strengthening national borders is one area of policy that the current UK government seems keen to develop. However, border control is an area of public policy which in itself is fraught with contradictions. Politicians of many persuasions wish to be seen to highly manage and regulate border controls to counterbalance popular fears regarding immigration and its 
perceived strain on social provision, housing stock and employment opportunities; yet to over-control borders would have profound effects on the economic wellbeing of the country, as global capital flows require, to some degree, the freedom of movement of peoples and commodities. Thus for those invested with making border control policy, this requires both a balancing act and a range of policy and rhetorical devices to retool the balance from time-to-time. The conjecture of this paper is that the alcohol minimum price per unit of alcohol policy has the potential to be deployed, in the future, as one of these devises. If we consider hypothetically that at some point in the future there is a perceived need to reinforce border controls, for example an increase in people entering the UK to seek asylum, then evidence of increased alcohol smuggling could provide the basis for the securing of border controls. Thus fears about loss of revenue, increasing crime and continued access to cheap alcohol beverages could be used as a precursor to shoring up the border of fortress Britain. In the masquerade of border control policy, any increase in smuggling as a result of the minimum alcohol pricing policy is a useful disguise with which to protect the nation.

\section{Last Orders (Conclusions)}

As we have seen, how we use alcohol and how the state attempts to regulate the use of alcohol has long been tied to notions of nationality and nationalism. The current policy agenda of minimum price per unit fixing continues this tradition. It is somewhat ironic that the policy is likely to be challenged by the European Union, because as we have seen Britain's relationship with other European nations has often been the catalyst for alcohol control policies.

The argument that the state's dealings with alcohol have had a long association with understand the nation and nationality is compelling, however the potential to use this 
policy as a precursor to strengthening or reinforcing national borders is somewhat worrying as it suggests a degree of premeditated deceit. This argument is purely conjecture, but there seem few other reasons for the UK coalition government to pursue a policy which has significant advantages for organised criminals.

From the historical analysis it is striking how pervasive alcohol has been, and continues to be, as a lens to view nationality, particularly as a deficit. From the gin craze of $18^{\text {th }}$ century London, via the bestially drunk Irish of the $19^{\text {th }}$ century to the street drinking Accession Eight nations of the $21^{\text {st }}$ century, alcohol has continued to provide a prism to view the shortcomings of national characteristics.

Furthermore, alcohol control policies have a long history of both influencing and being influenced by how national borders are understood and operated. From $18^{\text {th }}$ century duties on imported French brandy to the development of the powers and responsibilities of the US Coastguard Service during the period of national prohibition. In all cases of attempts to control the importation of alcoholic drinks has lead to the development of smuggling to either avoid law enforcement or customs and duties.

It would be easy to reduce these challenges and contradictions of alcohol controls to an economic imperative. The UK alcohol industry is powerful, both economically and politically, but commercial interest, in and of itself, cannot account for cultural understandings of alcohol as they relate to nationality and borders. Neither can a class analysis, although there are class dimensions to both popular ideas about alcohol consumption and policies to control its consumption. The evidence from $18^{\text {th }}$ century Scotland demonstrates this well. The fact that the Scots continued to imbibe claret after the Act of Union has little to with commercial imperative and not much to do with class antagonisms. Rather it was symbolic of Scottish independence and defiance of the English. 
Again, if we consider London's $18^{\text {th }}$ century gin craze, commercial interest and class analysis do not tell the whole story. Although there was an economic interest in promoting gin as a popular beverage, and its effects were, on the whole, felt by the poor, it was as much to do with England's relationship, or rather lack of relationship, with the French that gave rise to the chronic use of gin in $18^{\text {th }}$ century London. If we look forward from the $18^{\text {th }}$ century, through the $19^{\text {th }}$ century into our current time, how we understand the nation and nationality continues to inform our understand of alcohol and its control.

The popular notion of booze Britain continues this tradition of conflating commercial interests, notions of class deficit and nationality. This is somewhat symptomatic of the internal contradictions of alcohol control policies. These policies are supposed to objectively regulate consumption but this does not fit well in the context of the current dominant political ideology. By foregrounding issues of nationality, policy-makers can at the very least attempt to obscure this profound contradiction. It is this reification of the nation state and nationality that enables the differentiation of alcohol from other consumable commodities as distinct and in need of control.

Another contradiction involves the impact of the alcohol minimum pricing policy on the government of the British nation. If the impact of the policy is that the consumption of legally available alcohol reduces and the consumption of illegally imported alcohol increases, then this will inevitably result in reduced revenues for the UK treasury. Furthermore, the potential increased strain on controlling the national border could create further expenditure for the UK government.

To conclude, this latest policy agenda, of minimum price setting per unit of alcohol, could be viewed as a response to a popular discourse on the state of the nation commonly referred to as 'booze Britain'. This notion of national deficit has been employed as a rhetorical devise in 
order to impose regulation on the drinkers of Britain. This policy, in turn, has significant potential consequences for how the British state operates its border controls. Any changes to the operation of national borders have consequences for conceptualising the nation and therefore the notion of nationality. So, the debate come round full circle, a policy which has been informed by a popular discourse of nationality has the potential to then either shift or reinforce the notion of the nation and nationality. 


\section{List of references}

Adorno, T. W. (1991). The Culture Industry: Selected essays on mass culture. London: Routledge.

Anderson, B. (1991). Imagined Communities. London: Verso.

Bower, J., \& Cox, H. (2010). Political influence and hostile bids: How Scottish \& Newcastle became the UK's largest brewer Paper presented at the 14th Annual Conference of the European Business History Association, University of Glasgow.

Brockley, B. (2012). Drunkenness is a right not a privilege. Retrieved from http://brockley.blogspot.co.uk/2012/02/drunkenness-is-right-not-privilege.html

Engels, F. (1993). The Condition of the Working Class in England. Oxford: Oxford University Press.

Haywood, K., \& Hobbs, D. (2007). Beyond the binge in 'booze Britain': market-led liminalization and the spectacle of binge drinking. The British Journal of Sociology, 58(3), 437-456.

HMSO. (2010). Renewal of the 'Tackling Alcohol Fraud' strategy. Retrieved from http://customs.hmrc.gov.uk/channelsPortalWebApp/channelsPortalWebApp.portal?_nf pb=true\&_pageLabel=pageExcise_ShowContent\&id=HMCE_PROD1_030554\&propertyTy pe=document.

Holt, M. (Ed.). (2006). Alcohol: A Social and Cultural History. Oxford: Berg.

Leicester, A., \& O'Connell, M. (2012). How significant is a minimum unit price for alcohol of 40p: Institute for Fiscal Studies.

Ludington, C. (2006). "To the King o'er the Water" Scotland and Claret, c. 1660-1763. In M. Holt (Ed.), Alcohol: A Social and Cultural History. Oxford: Berg.

Maples, T. (2012). Gin and Georgian London. Last Orders: A social history of drinking(Chapter 4). 
Mares, D. (2001). Gangstas or lager louts? Working class street gangs in Manchester. In M. Klein, H. Kerner, C. Maxson \& E. Weitekamp (Eds.), The Eurogang Paradox: Street gangs and youth groups in the US and Europe (pp. 153-164). London: Kluwer Academic.

Marx, K. (1976). Capital (Vol. 1). London: Penguin.

Mill, J. S. (1859). On Liberty. London: Longman, Roberts and Green.

Mills, K., Knight, T., \& Green, R. (2007). Beyond Boundaries: offering substance misuse services to new migrants in London. London: Centre for Community Research, University of Hertfordshire.

Morgan, J. (2011). Why is alcohol consumption falling? Retrieved 24th April, 2012, from http://www.bbc.co.uk/news/magazine-12397254

Norman, J. (2012). Illegal Alcohol and Tobacco Sales. London: Hansard Retrieved from http://www.publications.parliament.uk/pa/cm/cmtoday/cmwhall/01.htm.

Rayner, J. (2004). On the streets of binge Britain Retrieved 27th March, 2012, from http://www.guardian.co.uk/travel/2004/sep/05/restaurants

Standing, G. (2011). The Precariat: The New Dangerous Class. London: Bloomsbury. Thompson, E. P. (1963). The Making of the English Working Class. London: Penguin. Valverde, M. (1998). Diseases of the Will: Alcohol and the dilemmas of freedom. Cambridge: Cambridge University Press. 